\title{
A 16S rDNA-based nested PCR protocol to detect Campylobacter gracilis in oral infections
}

\section{Protocolo de "nested" PCR baseado na fração 16S do rDNA para detecção de Campylobacter gracilis em infecções orais}

José Freitas Siqueira Júnior*

Isabela das Neves Rôças**

\begin{abstract}
The aim of this study was to describe a 16S rDNA-based nested polymerase chain reaction (nPCR) assay to investigate the occurrence of Campylobacter gracilis in oral infections. Samples were collected from ten infected root canals, ten cases of acute periradicular abscesses and eight cases of adult marginal periodontitis. DNA extracted from the samples was initially amplified using universal 16S rDNA primers. A second round of amplification used the first PCR products to detect C. gracilis using oligonucleotide primers designed from species-specific 16S rDNA signature sequences. The nPCR assay used in this study showed a detection limit of 10 C. gracilis cells and no cross-reactivity was observed with nontarget bacteria. C. gracilis was detected in the three types of oral infections investigated - 4/10 infected root canals; $2 / 10$ acute periradicular abscesses; and 1/8 subgingival specimens from adult periodontitis. The method proposed in this study showed both high sensitivity and high specificity to directly detect $C$. gracilis in samples from root canal infections, abscesses, and subgingival plaque. Our findings confirmed that C. gracilis may be a member of the microbiota associated with distinct oral infections, and its specific role in such diseases requires further clarification.

DESCRIPTORS: Campylobacter; Campylobacter infections; Polymerase chain reaction.
\end{abstract}

RESUMO: O objetivo deste estudo foi descrever um método de "nested" PCR baseado na fração 16S do rDNA para investigar a ocorrência de Campylobacter gracilis em infecções orais. Amostras foram coletadas de dez casos de canais radiculares infectados, dez casos de abscesso perirradicular agudo e oito casos de periodontite do adulto. O DNA extraído das amostras foi inicialmente amplificado usando "primers" universais para o gene do 16S rDNA. Uma segunda etapa de amplificação empregou os produtos de PCR gerados na primeira reação para detectar C. gracilis usando "primers" desenhados a partir de uma região específica para essa espécie localizada no gene do 16S rDNA. O método usado neste estudo apresentou um limite de detecção de 10 células de $C$. gracilis e ausência de reatividade cruzada com outras espécies bacterianas orais. C. gracilis foi detectado nos três tipos de infecções orais investigadas - 4/10 canais radiculares infectados; 2 / 10 casos de abscesso perirradicular agudo; e 1/ 8 espécimes subgengivais de casos de periodontite do adulto. O método proposto neste estudo foi altamente sensivel e específico na detecção direta de $C$. gracilis em amostras clínicas de infecções endodônticas, abscessos e placa subgengival. Nossos achados confirmam que $C$. gracilis pode ser um membro da microbiota associada com infecções orais distintas e seu papel específico em tais doenças requer posterior elucidação.

DESCRITORES: Campylobacter; Infecções por Campylobacter; Reação em cadeia da polimerase.

\section{INTRODUCTION}

Campylobacter gracilis is a non-motile, non-sporeforming, anaerobic Gram-negative rod with a formate- and fumarate-requiring metabolism. Many strains can even be microaerophiles ${ }^{3}$. Formate is oxidized to produce hydrogen and carbon dioxide, while fumarate is reduced to succinate. The specific epithet of $C$. gracilis was due to the slender tapered shape of cells after 4 to 6 days of anaerobic incubation on agar plates. Cells are small and straight, $0.4 \mu \mathrm{m}$ wide by 4 to
$6 \mu \mathrm{m}$ long, with round ends. The species has a $\mathrm{G}+\mathrm{C}$ content of 43 to $47 \mathrm{~mol}^{14}$.

This species was proposed and described by Tanner et al. ${ }^{14}$, in 1981, as Bacteroides gracilis. Further analyses of cellular fatty acid profiles indicated that $B$. gracilis were not "true" bacteroides ${ }^{2}$. In 1995, Vandamme et al. ${ }^{15}$, based on an analysis of the cellular fatty acids, respiratory quinones, and proteins of $B$. gracilis, and using previously published data for genotypic and phenotypic characteristics of this species, transferred it to the genus Campylobacter.

*Professor, Chairman; **Assistant Professor - Department of Endodontics, Estácio de Sá University. 
Siqueira Júnior JF, Rôças I das N. A 16S rDNA-based nested PCR protocol to detect Campylobacter gracilis in oral infections. Pesqui Odontol Bras 2003;17(2):142-6.

C. gracilis has been considered a probable important medical pathogen. Its primary habitat appears to be the gingival crevice and the majority of the infections caused by $C$. gracilis occur in the head and neck areas. It has been found associated with cases of root canal infections, gingivitis, adult periodontitis and periimplantitis ${ }^{5,6,11-13}$. Infections in the pleuropulmonary system and in the abdominal cavity as well as tubo-ovarian abscesses caused by $C$. gracilis have also been reported ${ }^{4,7,16}$. The potential difficulties in treating C. gracilis infections have been considered a major clinical concern in the management of some of these diseases ${ }^{4}$.

Because this species is not always easily identified by conventional culture methods, it is possible that its prevalence has been underestimated in some oral infections. Molecular methods, particularly the polymerase chain reaction (PCR) method, overcome many of the problems associated with traditional phenotype-based identification methods. PCR has been widely used to identify microbial species that are difficult to cultivate, unculturable species, and strains within a species that show a phenotypically divergent behavior and thereby are difficult to be identified by culture procedures. The PCR methodology has the highest detection rate between the microbiological identification methods, and under optimized conditions also shows high specificity. The nested PCR (nPCR) technique is a modification of the PCR technology that involves a first round of amplification of a DNA sequence with one set of primers followed by a second round of amplification using a second set of primers complementary to smaller sequences within the first PCR product. nPCR possesses increased detection rate and specificity when compared with single PCR.

The purpose of this study was to describe a species-specific nPCR assay to directly survey clinical samples from three types of oral infections for the presence of C. gracilis.

\section{MATERIALS AND METHODS Subjects and sampling procedures}

The material used in this study consisted of samples collected from adult patients with ages ranging from 18 to 65 years who had been referred for endodontic, emergency, or periodontal treatment to the School of Dentistry, Estácio de Sá University, Rio de Janeiro, RJ, Brazil. Samples were obtained from 10 infected root canals, 10 cases of acute periradicular abscesses, and 8 cases of adult marginal periodontitis. Cases of infected root canals and periradicular abscesses showed carious lesions, necrotic pulps and radiographically detected periradicular bone destruction. Periodontitis subjects had at least eight sites with pocket depths $>4 \mathrm{~mm}$ and no prior periodontal therapy.

Samples from infected root canals were collected as follows: after each tooth was cleansed with pumice and isolated with a rubber dam, the tooth and the surrounding field were then cleansed with $3 \%$ hydrogen peroxide and decontaminated with a $2.5 \%$ sodium hypochlorite solution. Complete access preparations were made using sterile burs without water spray. The operative field, including the pulp chamber, was then swabbed with $2.5 \%$ sodium hypochlorite. $\mathrm{NaOCl}$ solution was then inactivated by sterile $5 \%$ sodium thiosulphate. If the root canal was dry, a small amount of sterile saline solution was introduced into the canal. Samples were initially collected by means of a \#15 K-type file (Dentsply Maillefer, Ballaigues, Switzerland) with the handle cut off. The file was introduced to a level approximately $1 \mathrm{~mm}$ short of the tooth apex, based on diagnostic radiographs, and a discrete filing motion was applied. Afterwards, two sequential paper points were placed up to the same level and used to soak up the fluid in the canal. Each paper point was retained in position for $1 \mathrm{~min}$. The cut file and the two paper points were then transferred to cryotubes containing $1 \mathrm{ml}$ of 5\% dimethyl sulfoxide in trypticase-soy broth (TSB-DMSO) (Difco, Detroit, MI, USA) .

Samples of acute periradicular abscesses were collected as follows: after disinfection of the oral mucosa with $2 \%$ chlorhexidine, purulent exudate was aspirated using a sterile syringe. Pus was then transferred to TSB-DMSO and frozen.

Samples of adult marginal periodontitis were collected from 8 patients as follows: after sample sites were isolated with cotton rolls and air dried, the supragingival plaque was removed and paper points were inserted up to the depth of the pockets. Samples were taken from the 3 deepest periodontal pockets in each patient. Paper points were removed after 10 seconds and then placed into cryotubes containing TSB-DMSO and frozen. Thus, periodontal samples from each patient consisted of a pool of the three sampled diseased sites.

After collection, all samples were immediately frozen at $-20^{\circ} \mathrm{C}$. 
Siqueira Júnior JF, Rôças I das N. A 16S rDNA-based nested PCR protocol to detect Campylobacter gracilis in oral infections. Pesqui Odontol Bras 2003;17(2):142-6.

\section{Sample processing for PCR}

The samples in TSB-DMSO were thawed at $37^{\circ} \mathrm{C}$ for $10 \mathrm{~min}$ and vortexed for $30 \mathrm{~s}$. Microbial suspension was washed 3 times with $100 \mu$ of bidistilled water by centrifugation for $2 \mathrm{~min}$ at $2,500 \mathrm{x}$ g. Pellets were then resuspended in $100 \mu \mathrm{l}$ of bidistilled water, boiled for $10 \mathrm{~min}$ and chilled on ice. After centrifugation to remove cell debris for $10 \mathrm{~s}$ at $9,000 \mathrm{xg}$ at $4^{\circ} \mathrm{C}$, the supernatant was collected and used as the template for PCR amplification. Reference DNA from C. gracilis ATCC 33236 was also extracted to serve as positive control for the primers used. Extracted DNA from Actinobacillus actinomycetemcomitans (ATCC 43718), Bacteroides forsythus (ATCC 43037), Campylobacter rectus (ATCC 33238), Campylobacter showae (ATCC 51146), Capnocytophaga ochracea (ATCC 27872), Fusobacterium nucleatum (ATCC 25586 and 10953), Porphyromonas endodontalis (ATCC 35406), Porphyromonas gingivalis (ATCC 33277), Prevotella intermedia (ATCC 25611), Prevotella nigrescens (ATCC 33563), Streptococcus intermedius (ATCC 27335), and Treponema denticola (B1 strain, Forsyth Dental Institute, Boston, MA, USA) was also used to check for the specificity of $C$. gracilis primers.

\section{Universal 16S rDNA oligonucleotide primers}

In the first PCR reaction, a practically fulllength 16S rDNA was amplified using a pair of universal 16S rDNA primers, which consisted of a forward universal primer (5'- AGA GTT TGA TCC TGG CTC AG -3', base position 8-27 relative to Escherichia coli $16 \mathrm{~S}$ rDNA) and a reverse universal primer (5'- ACG GCT ACC TTG TTA CGA CTT -3', base position $1,493-1,513$ relative to $E$. coli $16 \mathrm{~S}$ rDNA).

\section{Design of C. gracilis specific primers}

PCR oligonucleotide primers specific for $C$. gracilis were designed using the published DNA data from the GenBank. Briefly, 16S rDNA sequences from the GenBank database were aligned, and variable areas between species were identified. Upstream and downstream C. gracilis primers were designed from these areas and Blast ${ }^{1}$ was used to verify their specificity by comparing primer sequences with all available sequences in the GenBank database. Blast search revealed no likely cross-reactivity with other related or unrelated oral species. Primer specificity was further tested against DNA from the reference strains used as controls. The PCR oligonucleotide species-specific primers, 16S rDNA-directed, for C. gracilis were 5'AAC GGA ATT TAA GAG AGC TT -3' (forward primer, located at base position 65-84 of the $C$. gracilis 16S rDNA, GenBank acession no. L04320) and 5'- CTT TCC CGA TTT ATC TTA TG -3' (reverse primer, located at base position 211-192 of the $C$. gracilis 16S rDNA, GenBank acession no. L04320), producing a PCR amplicon of $147 \mathrm{bp}$. Primers were synthesized by Oligos Etc. Inc. (Wilsonville, OR, USA).

\section{nPCR assay}

A $16 \mathrm{~S}$ rDNA-based nPCR detection method was used to detect $C$. gracilis in clinical samples. Aliquots of $5 \mu 1$ of the supernatant from clinical samples were used as target in the first round of PCR amplification using universal 16S rDNA primers. PCR amplification was performed in $25 \mu \mathrm{l}$ of reaction mixture containing $0.2 \mu \mathrm{M}$ concentration of forward and reverse universal primers, $2.5 \mu 1$ of 10 X PCR buffer, $2 \mathrm{mM} \mathrm{MgCl}_{2}, 1.25 \mathrm{U}$ of Taq DNA polymerase (Gibco BRL, Gaithersburg, Md, USA) and $25 \mu \mathrm{M}$ concentration of each deoxynucleoside triphosphate (dATP, dCTP, dGTP, and dTTP) (Gibco BRL).

Afterwards, $1 \mu 1$ of the universal reaction was then used as template for the second round of PCR amplification, which was directed towards the specific detection C. gracilis. The second PCR reaction was performed in a $50 \mu 1$ of reaction mixture containing $1 \mu \mathrm{M}$ of each specific primer, $5 \mu \mathrm{l}$ of $10 \mathrm{X}$ PCR buffer (Gibco BRL), $2 \mathrm{mM} \mathrm{MgCl}_{2}$, 1.25 unit Taq DNA polymerase (Gibco BRL) and $0.2 \mathrm{mM}$ of each deoxyribonucleoside triphosphate (Gibco BRL). PCR reactions were performed in 25-well microtiter plates.

Preparations were amplified in a DNA thermocycler (Primus 25/96, MWG-Biotech, Ebersberg, Germany). Cycling parameters for the first PCR reaction using universal primers included an initial denaturation step at $97^{\circ} \mathrm{C}$ for $1 \mathrm{~min}$, followed by 26 cycles of a denaturation step at $97^{\circ} \mathrm{C}$ for $45 \mathrm{~s}$, a primer annealing step at $55^{\circ} \mathrm{C}$ for $45 \mathrm{~s}$, an extension step at $72^{\circ} \mathrm{C}$ for $1 \mathrm{~min}$ and a final step at $72^{\circ} \mathrm{C}$ for $4 \mathrm{~min}$. Temperature profile for the second round of amplification, which was specific for C. gracilis, included an initial denaturation step at $95^{\circ} \mathrm{C}$ for $2 \mathrm{~min}$, followed by 26 cycles of a denaturation step at $94^{\circ} \mathrm{C}$ for $30 \mathrm{~s}$, a primer annealing step at $53^{\circ} \mathrm{C}$ for $1 \mathrm{~min}$, an extension step at $72^{\circ} \mathrm{C}$ for $1 \mathrm{~min}$ and a final step at $72^{\circ} \mathrm{C}$ for $2 \mathrm{~min}$. 
Siqueira Júnior JF, Rôças I das N. A 16S rDNA-based nested PCR protocol to detect Campylobacter gracilis in oral infections. Pesqui Odontol Bras 2003;17(2):142-6.

PCR products were analyzed by electrophoresis in a $1.5 \%$ agarose gel at $4 \mathrm{~V} / \mathrm{cm}$ in Tris-borateEDTA buffer. The gel was stained for 15 min with $0.5 \mu \mathrm{g} / \mathrm{ml}$ ethidium bromide and photographed under ultraviolet light. Positive reactions were determined by the presence of bands of the appropriate sizes. A 100 bp DNA ladder digest (Gibco BRL) served as the molecular size standard.

\section{RESULTS}

Amplification of reference genomic DNA of $C$. gracilis ATCC 33236 yielded a single $147 \mathrm{bp}$ band. Clinical samples that were positive for $C$. gracilis also showed only one band of the predicted size. The detection limit of the nPCR assay used in this study was approximately 10 C. gracilis cells as determined by amplification of serial dilutions of templates prepared from C. gracilis genomic DNA. No amplification was detected for any of the reference strains that were not $C$. gracilis. Figure 1 depicts representative $C$. gracilis specific amplicons obtained after nPCR amplification of reference DNA and clinical samples.

Species-specific nPCR for C. gracilis allowed the detection of this species in 4/10 infected root canals, 2/10 abscessed cases, and 1/8 subgingival specimens of adult marginal periodontitis.

The first round of amplification using universal primers for the 16S rDNA generated a product of the expected size $(1,505 \mathrm{bp})$. This revealed that bacteria were present in all cases examined, demonstrated the suitability of bacterial DNA for PCR analysis, and indicated that PCR was conducted without significant inhibition by components of the clinical samples.

\section{DISCUSSION}

The nPCR assay described in this study to directly detect $C$. gracilis in oral infections showed both high sensitivity and high specificity. The specificity of the oligonucleotide primers is important to avoid false positive results when using PCR. C. gracilis is closely related to $C$. rectus and $C$. showae, based on 16S rDNA sequencing, and shares many of their characters. We observed no evidence of cross-reactivity when checking the $C$. gracilis specific primers against a panel of twelve non-targeted oral species, including the closely related species $C$. rectus and $C$. showae. Non-specific amplification products were also absent. Therefore,

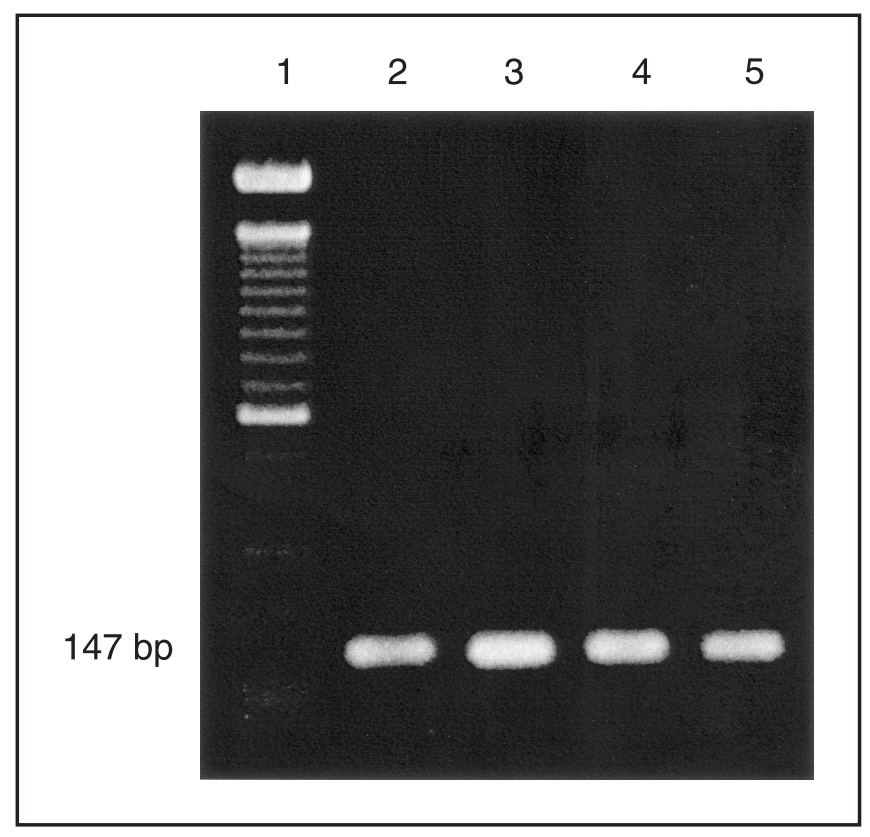

FIGURE 1 - Representative PCR generated amplicons in electrophoresis. Lane 1, 100 bp ladder; Lanes 2 to 5, amplification using Campylobacter gracilis specific primer; Lane 2, C. gracilis DNA (control); Lanes 3 to 5, C. gracilis in a clinical sample.

the method's specificity for C. gracilis detection was high.

The high detection rate of $\mathrm{nPCR}$ approaches may be a reason of concern, particularly when non-quantitative assays are employed. It has been claimed that because PCR can detect a very low number of cells of a given species, the results obtained by this method may not have significance with regard to etiology of a given disease. Although this must be really taken into account when analyzing nPCR results, some other factors should be also considered in this discussion, which represent great advantages of such highly sensitive identification procedure. First, because there is no agreed bacterial load for clinically inducing periradicular and periodontal diseases, it would be obviously prudent that the method of assay should detect the smallest number possible of bacterial cells in samples. Here lies one of the greatest advantages of the nPCR. Second, the method used in this study has a detection limit of approximately 10 cells of the target species. If one considers that a $5 \%$ volume of the original sample $(100 \mu 1)$ was used in individual PCR experiments, the detection limit was then approximately 200 cells in the whole sample, which is still more sensitive than other 
Siqueira Júnior JF, Rôças I das N. A 16S rDNA-based nested PCR protocol to detect Campylobacter gracilis in oral infections. Pesqui Odontol Bras 2003;17(2):142-6.

identification methods but can be also significant with regard to etiology of the disease.

C. gracilis was detected in the three types of oral infections examined. Prevalence values do not deserve speculations about the role of this species in each disease because of the low number of samples investigated. However, our findings demonstrated that the method was effective in detecting $C$. gracilis in samples from root canal infections, abscesses, and subgingival plaque. All these infectious diseases are usually characterized by a mixed infection ${ }^{8-11}$. Therefore, the nPCR method used he-

\section{REFERENCES}

1. Altschul SF, Gish W, Miller W, Myers EW, Lipman DJ. Basic local alignment search tool. J Mol Biol 1990; 215:403-10.

2. Brondz I, Olsen I. Multivariate analyses of cellular fatty acids in Bacteroides, Prevotella, Porphyromonas, Wolinella, and Campylobacter spp. J Clin Microbiol 1991; 29:183-9.

3. Han YH, Smibert RM, Krieg NR. Wolinella recta, Wolinella curva, Bacteroides ureolyticus, and Bacteroides gracilis are microaerophiles, not anaerobes. Int $\mathrm{J}$ Syst Bacteriol 1991;41:218-22.

4. Johnson CC, Reinhardt JF, Edelstein MA, Mulligan ME, George WL, Finegold SM. Bacteroides gracilis, an important anaerobic bacterial pathogen. J Clin Microbiol 1985;22:799-802.

5. Kamma JJ, Diamanti-Kipioti A, Nakou M, Mitsis FJ. Profile of subgingival microbiota in children with primary dentition. J Periodontal Res 2000;35:33-41.

6. Le Goff A, Bunetel L, Mouton C, Bonnaure-Mallet M. Evaluation of root canal bacteria and their antimicrobial susceptibility in teeth with necrotic pulp. Oral Microbiol Immunol 1997;12:318-22.

7. Lee D, Goldstein EJ, Citron DM, Ross S. Empyema due to Bacteroides gracilis: case report and in vitro susceptibilities to eight antimicrobial agents. Clin Infect Dis 1993;16 Suppl 4:S263-5.

8. Siqueira Jr JF, Rôças IN, Souto R, Uzeda M, Colombo AP. Checkerboard DNA-DNA hybridization analysis of endodontic infections. Oral Surg Oral Med Oral Pathol Oral Radiol Endod 2000;89:744-8. rein also showed the capacity to detect $C$. gracilis against a background of other bacterial species.

\section{CONCLUSION}

The 16S rDNA-based nPCR approach proposed in this study to identify $C$. gracilis was highly sensitive, specific, and capable to directly detect this species in clinical samples from oral infections. The use of this method may help to delineate the role of C. gracilis in different oral infectious diseases.

9. Siqueira Junior JF, Rôças IN, Souto R, Uzeda M, Colombo AP. Microbiological evaluation of acute periradicular abscesses by DNA-DNA hybridization. Oral Surg Oral Med Oral Pathol Oral Radiol Endod 2001;92:451-7.

10. Socransky SS, Haffajee AD, Dzink JL, Hillman JD. Associations between microbial species in subgingival plaque samples. Oral Microbiol Immunol 1988;3:1-7.

11. Sundqvist G. Associations between microbial species in dental root canal infections. Oral Microbiol Immunol 1992;7:257-62.

12. Tanner A, Maiden MF, Lee K, Shulman LB, Weber HP. Dental implant infections. Clin Infect Dis 1997;25 Suppl 2:S213-7.

13. Tanner A, Maiden MF, Macuch PJ, Murray LL, Kent Jr. RL. Microbiota of health, gingivitis, and initial periodontitis. J Clin Periodontol 1998;25:85-98.

14. Tanner ACR, Badger S, Lai C-H, Listgarten MA, Visconti RA, Socransky SS. Wolinella gen. nov., Wolinella succinogenes (Vibrio succinogenes Wolin et al.) comb. nov., and description of Bacteroides gracilis sp. nov., Wolinella recta sp. nov., Campylobacter concisus sp. nov., and Eikenella corrodens from humans with periodontal disease. Int J Syst Bacteriol 1981;31:432-45.

15. Vandamme P, Daneshvar MI, Dewhirst FE, Paster BJ, Kersters K, Goossens H, Moss CW. Chemotaxonomic analyses of Bacteroides gracilis and Bacteroides ureolyticus and reclassification of $B$. gracilis as Campylobacter gracilis comb. nov. Int J Syst Bacteriol 1995;45:145-52.

16. Yu WL, Chen WY. Tubo-ovarian abscess caused by multidrug resistant Bacteroides gracilis. J Formos Med Assoc 1997;96:457-60.
Recebido para publicação em 23/07/02

Enviado para reformulação em 02/10/02

Aceito para publicação em 16/04/03 